\title{
COMMUNICATION, FEAR AND COLLECTIVE TRAUMA IN FIRST WAVE COVID-19 “DOUBLE EPIDEMIC” IN ITALY: TRACES AND CLUES'
}

\author{
COMUNICACIÓN, MIEDO Y TRAUMA COLECTIVO EN LA PRIMERA OLA DE LA \\ “DOBLE EPIDEMIA” DE COVID-19 EN ITALIA: RASTROS Y PISTAS
}

\author{
Guido Nicolosi \\ University of Catania. Catania, Italy \\ ORCID: 0000-0002-1219-2244 \\ gnicolos@unict.it

\begin{abstract}
The Coronavirus epidemic has demonstrated just how unprepared our societies were for an occurrence of this kind. On March 2020, the Italian government was in fact the first in Europe to implement a strategy of lockdown on the whole national territory, not just in the areas where outbreaks occurred. The coronavirus crisis was concentrated in a specific area: in particular, the region of Lombardy and some isolated provinces in the north of Italy. So, Italy has suffered a "double" epidemic, but the strategy adopted was uniform and radical. This contribution does not focus on the effectiveness of the Italian strategy per se. The aim is rather to analyse the Italian Case from the point of view of media and institutional communications with the intention of bringing to light some critical issues. Particularly, here it is posited that emergency communication produced during the "first wave" of pandemic has significantly contributed to fostering a climate of anxiety and collective fear with possible traumatogenic consequences. Within an emergency context, communication can be the thin boundary line between collective trauma and resilience and covid 19 pandemic was also a public communication crisis. This essay tries to analyse some traumatogenetic issues of institutional and media communication during the coronavirus crisis in Italy. Below a non-exhaustive list of these issues: A dramatic center-periphery coordination deficit; Wavering institutional communication; The "numerological" hegemony"; The absence of an "exit strategy".
\end{abstract}

Keywords: Pandemic; Infodemic; Fear; Anxiety; Trauma.

| Resumen | La epidemia del coronavirus ha demostrado con precisión, lo poco preparadas que estaban nuestras sociedades para un acontecimiento de este tipo. En marzo de 2020, el gobierno italiano fue de hecho el primero en Europa en implementar una estrategia de bloqueo en todo el territorio nacional, no solo en las áreas donde ocurrieron los brotes. La crisis del coronavirus se concentró en un área específica: en particular, la región de Lombardía y algunas provincias aisladas del norte de Italia. Se desprende de este hecho que Italia ha sufrido una epidemia "doble", mas la estrategia adoptada fue uniforme y radical. Esta contribución no se centra en la eficacia de la estrategia italiana per sé. El objetivo es más bien analizar el caso italiano desde el punto de vista de la comunicación mediática e institucional con la intención de sacar a la luz algunas cuestiones críticas. En particular, aquí se postula que la comunicación de emergencia producida durante la "primera ola" de pandemia ha contribuido significativamente a fomentar un clima de ansiedad y miedo colectivo con posibles consecuencias traumáticas. En un contexto de emergencia, la comunicación puede ser la delgada línea divisoria entre el trauma colectivo y la resiliencia y la pandemia de Covid 19 también fue una crisis de comunicación pública. Este ensayo intenta analizar algunos problemas traumatizantes de la comunicación institucional y mediática durante la crisis del coronavirus en Italia. A continuación, se presenta una lista no

'Recibido/Received: 30/04/2021

Aceptado/Accepted: 07/06/2021 
Communication, fear, and collective trauma in first wave Covid-19

"double epidemic" in Italy: Traces and clues

exhaustiva de estos temas: Un dramático déficit de coordinación centro-periferia; comunicación institucional vacilante; la hegemonía "numerológica"; la ausencia de una "estrategia de salida".

Palabras clave: Pandemia; Infodemia; Miedo; Ansiedad; Trauma.

\section{| Introduction |}

The Coronavirus epidemic has ruthlessly demonstrated just how unprepared our societies were for an occurrence of this kind. Yet, according to many scientists and the World Health Organisation (WHO), the potential threat of a pandemic that would devastate the planet's health and economy was clearly announced at least 15 years ago (Quammen, 2013). On the international front, one of the most seriously affected nations was Italy. It was the first in Europe to face the exponential rise in infections, hospital admissions, patients in intensive care, and deaths. The dramatic developments of the Italian situation were interpreted by many as confirmation of the pessimistic forecasts by some epidemiologists, testifying to the disastrous consequences of overloading the national health service.

On March 2020, the Italian government was in fact the first in Europe to implement a strategy of lockdown on the whole national territory, not just in the areas where outbreaks occurred, as suggested by the Comitato Tecnico-Scientifico (CTS). ${ }^{2}$ This was possibly the most radical step taken on the Old Continent ${ }^{3}$ although it is now evident that the "first wave" of epidemic has not affected the nation in a uniform manner. The coronavirus crisis was concentrated in a specific area: in particular, the region of Lombardy and some isolated provinces in the north of Italy. In general, the Southern regions (in particular the islands) have only been marginally affected ${ }^{4}$. The experts all affirm that the implementation of lockdown cannot explain the different regional reactions to the virus ${ }^{5}$; the reasons are multiple and "endemic"'. Significant geographical differences remain even today, after one year.

Consequently, from March to May 2020, Italy has suffered a "double" epidemic even though the strategy adopted was uniform and radical. This contribution does not focus on the effectiveness of the Italian strategy per sè; such a discussion goes beyond the author's competence. The aim is rather to analyse the Italian Case from the point of view of media and institutional communications with the intention of bringing to light

\footnotetext{
2 The Comitato Tecnico Scientifico (CTS) is a scientific task force supporting the Italian Government to face the Covid 19 crisis. ${ }^{3}$ Even in China only the region of Wuhan was closed down.

${ }^{4}$ Until July 2020, the region of Lombardy had registered approximately $40 \%$ of infections (50\% of deaths). $75 \%$ of infections ( $80 \%$ of deaths) were concentrated in only 5 regions (Lombardy, Piedmont, Emilia-Romagna, Veneto and Tuscany) out of 20. The majority of infections and deaths were concentrated in clusters identified in specific provinces (Bergamo, Cremona, Lodi, Mantova, Pavia). In Sicily, in July 2020, since the beginning of the pandemic 3500 positive cases registered with 282 official deaths, respectively $0.07 \%$ and $0.006 \%$ of the population.

${ }^{5}$ By mid-April only in Sicily approximately 40,000 people returned to Sicily from Northern Italy (of whom only 20,000 traced), 8,000 just from Lombardy. These hordes of people returning South should have provoked widespread infection, which was not the case. Most significantly, comparable levels of hospital admissions and deaths comparable to those in the North have not been registered. "According to research carried out at the University of Catania entitled "Strategies to mitigate the Covid 19 pandemic risk", atmospheric pollution from Pm10, cooler temperatures, mobility, density and age of the population, number of hospitals and care and nursing homes, and population density are likely causes for the spread of infection in the North.
} 
some critical issues. Particularly, here it is posited that emergency communication produced during the "first wave" of pandemic has significantly contributed to fostering a climate of anxiety and collective fear with possible traumatogenic consequences. The reach of this emergency communication has assumed particularly relevant and paradoxical forms in view of the considerable territorial differences indicated above: in specific areas of the country we can probably report a symbolic relative overrepresentation of the pandemic.

This doesn't mean that the virus in these areas does not circulate or kill. We introduce the notion of "imagined" traumatic event, the kind of process that Benedict Anderson describes in Imagined Communities (Anderson, 1991). As Alexander (2004) pointed out, imagination informs trauma construction just as much when the reference is to something that actually occurred as to something that has not. The term "imagined" here is more like what Durkheim called "religious imagination", that is a form of social representation (Durkheim, 1912). The issue therefore concerns both the perception of risk and the social representation of the actual or potential impact of the catastrophic event (here the pandemic).

As a premise, we announce that we refuse the theoretical approach to disaster based on the "pattern of war" (Quarantelli, 1998): that is an external material agent to whom human communities react. In our perspective, disasters must be studied within the human group involved: that is social vulnerabilities ${ }^{7}$. Moreover, we define a disaster as a crisis based on the upsetting of the system of meaning in which culture and communication play a fundamental role in the interpretation of chaotic and confused situations (Fritz, 1968). Somehow, disaster is less an accident of reality than a disaster is the representation of reality (Gilbert, 1988). Like any other disaster, coronavirus pandemic was therefore a catastrophic event based on material elements (virus, health system capacity, infections, ICU admission rates, deaths, etc.) and immaterial or symbolic elements (risk perception, cultural elaboration of the threat, etc.). Our thesis here is that the balancing of the mix of these elements has been different in the North and in the South of the country.

This article does not aim to demonstrate that the coronavirus crisis in Italy will certainly produce a cultural trauma. Cultural traumas must be studied in retrospect from a distant point in time, allowing one to isolate a point of origin and then trace the ensuing meaning struggle through a range of forums and media, toward memorialization and the impact with regard to collective memory. Moreover, cultural traumas are not the aggregate of individual traumas, but a specific form of collective trauma, affecting collective identity. However, in this phase, it is very important to analyse whether or not there are some preliminary conditions for the generation of a collective trauma. In this explorative analysis, we try to find some traces or clues of it.

\footnotetext{
${ }^{7}$ Vulnerability is the quality or state of being exposed to the possibility of being harmed, either physically, or culturally. The concept looks at how various social groups or communities exposed to shocks and stressors are, potentially, affected, and how they differ in terms of their sensitivity and coping capacity, with an emphasis on spatial, physical, and social characteristics.
} 
The first section of this contribution offers a brief overview of the studies that demonstrate the relationship between media communications and collective trauma with specific reference to emergency conditions. The second section presents the principle critical aspects of institutional and mediatic communication during the coronavirus emergency in Italy from March to May 2020. Finally, the concluding section reflects on the possible collective psycho-social traumas produced by the Italian emergency communications in Italy regarding Covid- 19 .

\section{| Collective trauma, media and epidemic |}

The word trauma derives from the Greek тpaũ $\mu \mathrm{a}$ and means to damage, to harm. It also contains a double reference to a wound with lacerations and to the effects of a violent shock to the entire human organism. Originally used in the field of surgical medicine during the $18^{\text {th }}$ century, the term was later applied to psychiatry and clinical psychology to indicate the overwhelming effect on the capacity of the individual to cope with certain stimuli.

The first authors to refer to traumatism in a psychological sense were Pierre Janet (2016) and J.M. Charcot (1887). Nevertheless, the concept of trauma had always played a central role in the psychoanalytical theories of culture. It was indeed Freud (1913) who first extended its use beyond the confines of the individual to include the collective and the social. The sociologist Kai Erikson (1991) has provided a rigorous definition of the concept of collective trauma, referring to it as a "blow to the basic tissues of social life", damaging the bonds between people and putting the sense of community at risk.

More recently, Jeffrey Alexander (2004:1) used the expression of cultural trauma referring to a specific condition where "members of a collectivity feel they have been subjected to a horrendous event that leaves indelible marks upon their group consciousness, marking their memories forever and changing their future identity in fundamental and irrevocable ways". In his seminal work, he also demonstrated the important role played by media in the process of "social construction" of collective traumas. Particularly, mediated communication helps traumas to be expressively dramatized and supports some competing interpretations in obtaining persuasive powers over others.

Freud's teachings, however, had already been reclaimed and reintroduced by various exponents of the Frankfurt School (Benjamin and Adorno) incorporating them in a theory of "historical trauma" (with particular reference to the Holocaust) during the 20 s and 30s. Above all, they were integrated within the theory of cultural industry, identifying for the first time the nexus between mediated experience and traumatic conditions in scientific literature on the social effects of the media. This aspect was widely confirmed and discussed in the following years by multiple theoretical approaches of the sociology of mass communication (Wolf, 1985). For example, Charles Wright 
(1959), prominent figure within the school of functionalism, identified amongst the main possible dysfunctions of the mass media the production of panic, counterbalanced by the function of warning (against real or potential imminent threats).

More generally, trauma studies have demonstrated how it is possible to consider the media as decisive actors for understanding the traumatogenic dynamics of contemporary society (Meek, 2010). In this sense, a fundamental technical watershed was the advent of photography and its "reality effect" (Barthes, 1980) ${ }^{8}$. It is likely that the first example of "traumatic" photography coincides with the first example of "humanitarian" photography, aimed at raising awareness in western public opinion, rendering it "eye witness" to a drama: it was 1897 and the popular general interest magazine Cosmopolitan published Julian Hawthorne's reportage on India whose shocking images narrates starvation and pestilence in the former British colony (Fehrenbach and Rodogno, 2016). Since then, important moments in the history of "traumatic" photography have been many: without doubt, the most impactful examples are the photographic documentation of Nazi concentration camps (Del Porte, Veyrat-Masson, 2018), and in recent times, the dramatic images of the attack on the World Trade Centre in New York on the $11^{\text {th }}$ September 2001, emblematically defined by Allan Meek as a "virtual trauma".

Communities hit by epidemics show the apparent tendency to develop amnesia and remove the dramatic days that marked the temporary triumph of death, chaos and social disorder (La danse macabre, in French). In reality, the collective memory supported by multiple forms of media representation (literature, architecture, monumental, popular narratives, legends, etc.) constantly bring to the surface the trauma of the past (Erll and Nünning, 2010; Erll and Rigney, 2012). This process has taken on a parossistic form in the present era, so that when an epidemic breaks out in a community, the mass media bombard the population with stories, comparisons, and parallels with previous experiences of epidemics. This happened during the SARS-COV-2 pandemic; comparisons were made with EVD (Ebolavirus), or with the so-called "swine flu", H1N1, not to mention the Spanish flu, and were obsessively recurrent.

Even mere information can have serious traumatic effects. Many psychological studies have demonstrated over the years that aside from the risks to physical health connected to the threat (health, terroristic, emergency, environmental, etc.) that increasingly characterise globalised society and impose effective strategies of evaluating and communicating the risk, another threat has emerged with a higher profile: psychological distress deriving from repeated exposure to media with alarmist and anxiogenic content. This refers to the immediate impact on the population (already under stress due to the social and economic consequences of serious adverse events), and of a physical and mental nature over a long period. Longitudinal studies, in fact, have demonstrated that the significant rise in stress levels registered during or immediately after a catastrophic-

\footnotetext{
${ }^{8}$ An effect which, it should be pointed out, disregards the effective status of documental source. It is well known that many "realistic" photographs that have impacted on the collective imagination, even changing the course of history (for example: The Death of a soldier by Robert Capa, 1936) subsequently turned out to be manipulations or reconstructions artificially created (Burke, 2017): fakes that can represent the real better than reality.
} 
emergency event, is associated with significant negative repercussions on physical and mental health over time (Garfin, Thompson, Holman, 2018).

Yet, as well documented in the literature, during crises the public increases its dependence on the media (Ball-Rokeach \& De Fleur, 1976). In particular, in the case of health emergencies the public relies on the media to obtain accurate updates in order to make informed decisions on correct behaviour and health protection for themselves and for others. For this reason, it is essential that reliable and authoritative sources are available so that an accurate risk assessment can be made. Empirical research shows that the public can form an accurate perception if the media present the facts in an effective manner (Fischoff, et al., 2018). In contrast, the lack of information, ambiguous or contradictory information, incoherent messages, or communicative confusion, can lead to a dangerous rise in the perception of risk (Bishop et al., 2015; Jones et al., 2017; $\mathrm{WHO}, 2003)$. Field research demonstrates how much this negative effect is particularly marked when ambiguity regarding an invisible threat, as in the case of a virus. In this case, fear and panic can exacerbate and contribute to the diffusion of incorrect and unhelpful information. Emphatic or ambiguous media communication that increases the level of social panic can have damaging effects on the population's stress levels and provoke overloading on the nation's health service or the inaccessibility to services and products necessary to deal with the emergency. We have witnessed similar phenomena in all counties during the Covid 19 crisis: overflowing hospitals, masks and alcohol unavailable, supermarkets running out of toilet paper.

Images play a crucial role in media representations. We live within an extensive and pervasive "visual culture" (Pinotti and Somaini, 2016) and we have been witnessing a gradual replacement / integration of direct and personal experience with observation and mediated interaction (Van Dijk , 1999) as the photographic and cinematographic visual must certainly be considered a fundamental result of modern technology (Parikka, 2019). ${ }^{9}$ Images are a potent means of communication: they draw attention, function as metaphor, condense complex information, arouse emotions, stimulate memory. Images can serve as powerful tools to help people understand various aspects of risks and their alternatives (Lundgren and Mcmakin, 2018) and they are comprehensible beyond linguistic diversity (Mantovani e Ravarotto, 2016). However, images have a semiotically ambiguous aspect (signs that are insufficiently codified and liable to interpretative variability), which is a source of potentially dangerous effects. Exposure to images, graphics or infographics is anxiogenic in the case of collective trauma and can provoke an increase in post-traumatic stress and levels of fear in the mid-term (Holman et al., 2020).

Despite the evident difficulties in producing balanced media communication that is neither alarmist, nor an underestimation of the risks, it is imperative that the media avoid sensationalism, disturbing images and contradicting information. Let's not forget that in an emergency situation the public is also the victim that needs to be reassured.

9 The French philosopher Guy Debord, at the end of the 1960s, also echoing the intellectual experience of the Frankfurt School,
prophetically predicted that, at the end of the 20th century, heavy industry, of a Fordist style, would be completely supplanted by a
new a much lighter form: the society of the spectacle (Debord, 1967). SHJ, I (I) (202I) pp. 103-I26. ISSN: 2792-3967 
Reassurance does not emerge from the denial of risk (Reynolds 2014), on the contrary, minimization is an erroneous strategy that contributes to feeding a sense of panic. Instead, reassurance transpires with the demonstration of awareness and competence on the part of the interested authorities (scientists, institutions, politicians, and so on) and by implementing measures to tackle the problem, which can sometimes be very simple (Sturloni, 2018).

The context is currently rendered particularly complex by the social media, arena of social debate and also vehicle of amplification of feelings and of "scientific scepticism" or "wisdom of the crowd"10, phenomena that for years have eroded the climate of trust that supports the institutions and without which no communication would be effective ${ }^{11}$. The phenomenon is deep and originated before the advent of social media. Reducing everything to a simple question of ignorance, credulity, or fake news would mean not grasping the real importance of the process ${ }^{12}$. The influence of the social media is certainly growing and appears to be decisive for the future of effective risk communication.

\section{| The media and institutional communication in Italy during the Covid 19 emergency}

Recent sociological literature has widely demonstrated that ours is a "Risk Society" (Beck, 2000; Giddens, 1990; Luhmann, 1993), but danger, crisis, emergency are not objective categories because they are always reformulated by symbolic, contextual mediation. These categories are, then, in part "real" and in part "socially constructed". What counts in the so-called "acceptability" of risk, is its perception. The latter is radically influenced (amplified or attenuated) by a plurality of psychological, ethical, political and cultural factors (Pidgeon, Kasperson, Slovic, 2003). Communication plays a decisive role and has important consequences on the behaviour of individuals, especially in delicate moments during the handling of the emergency.

In 2019 the "Global Health Security Index", which measures the capacity for prevention and control of a possible pandemic, placed Italy in thirty-first position. Italy is lagging behind and is paying the price now for a historical deficit in relation to the structural limits of its public administration. Many important issues were raised in the report; however, specifically it highlighted that the only indicator in which Italy was well below the world average (only 25 points out of 100 out with the average of 39.4 ) was, in fact,

\footnotetext{
${ }^{10}$ The wisdom of the crowd (or intelligence of the crowd) is a theory according to which a mass of non-expert individuals are able to provide adequate and valid answers to a question better than the experts themselves.

${ }^{11}$ Trust is such a valuable asset that often judgements on risk in reality reflect a judgement on the credibility of institutions who are called upon manage it (Langford, Marris, O'Riordan, 2001). Trust is hard-won and over a long period but can easily be lost in an instant (Slovic, 2000).

12 "Non-vax" stances, for example, are as old as vaccines themselves and have been manifested in diverse social groups with various educational, gender, and social class divides.
} 
"risk communication". This critical condition is particularly relevant if we define a disaster as a disorder triggered by communication problems (Lagadec, 1988).

The outbreak of Coronavirus has unfortunately demonstrated how the findings of the GHS Index were ominously prescient. Italy demonstrated profound and worrying problematics with emergency communication, particularly regarding the quality and quantity. According to an investigation carried out in March and April 2020 by the independent research centre "Observa - Science and Society", only 20\% of Italians in the month of March and $14.7 \%$ in the month of April used institutional sources (Ministries, regional governments and so on) as means of gleaning information on Covid 19 , while only $6.5 \%$ (in April $1.7 \%$ ) obtained information by their family doctors even though these were considered the most reliable for obtaining information on the precautions to be adopted. The majority of Italians (52.1\% in March, and 66.6\% in April) obtained information from radio and television news broadcasts. The press (online and traditional formats), on the other hand, remained stable at 10 and 11\% (graph 1).

Institutional communication, therefore, was not pervasive as a source of public information, which in itself is a critical point. In fact, due to the management, economic, political and social implications of disastrous events, the role of institutional communication during an emergency is fundamental. Furthermore, it is essential that appointed institutions carry out the necessary planning and preparation before those events strike (Anzera, 2014). During the Coronavirus epidemic, communication was predominantly "managed" by the traditional media, even that produced by the institutions, and was by far the main source of information (77\% between radio, television, and traditional press in April). ${ }^{13}$ Auditel's ${ }^{14}$ data reveals that an enormous amount of information on coronavirus appeared on national news programmes: from 24 to $38 \%$, with peaks of $60 \%{ }^{15}$ (AGCOM, 2020). Television programming was revolutionised to accommodate the flow of related news and audience figures for political talk shows rose sharply. Above all, the increase was detected in the younger age groups who for years had been shifting from legacy media such as television towards the Internet and the social media.

As predicted by The Lancet ${ }^{16}$, Italy had to face an infodemic crisis and a pandemic information overload. ${ }^{17}$ This has been widely confirmed by our routine research activity. In the absence of effective, professional institutional direction, the media did not hesitate to dramatize the narration of events for their own interest (audience), with massive coverage which was at times emphatic, others schizophrenic (alternating reassurances with alarmism). On occasions they might even be accused of foul play, with headlines for effect and news which was only partially true. Science is inevitably exposed to diverse

\footnotetext{
13 These data have been substantially confirmed in October 2020 by the "Istituto per la formazione al giornalismo" (IFG) of Urbino (see the report "La scienza e il covid 19") and by the annual report of AGCOM (Autorità per le Garanzie nelle Comunicazioni).

${ }^{14}$ Auditel is a private company that measures Italian TV ratings.

15 These data have been confirmed by the annual AGCOM report: "L'impatto del coronavirus nei settori regolati. Allegato alla relazione annuale" (2020).

${ }^{16}$ Editorial Published Online July 17, 2020 https://doi.org/10.1016/ S1473-3099(20)30565-X

17 The term infodemic typically refers to a rapid and far-reaching spread of both accurate and inaccurate information about something, such as a disease. It concerns both the quantity and quality of information.
}

SHJ, I (I) (202I) pp. 103-I26. ISSN: 2792-3967 
interpretations, but the continuous representation of a "disassociation" produced by media logics paved the way for widespread scepticism regarding the capacity of science to comprehend and control the phenomenon. ${ }^{18}$

It should be remembered that one of the factors that drove ordinary people to approach the "myths" and abandon the "facts" is precisely the contradictory scientific interpretations (Riva, 2018). In emergency conditions, the lack of coherence in interpreting the "cause" (in this case coronavirus) is a destabilising factor for the public. The conflict between physicians and virologists which has been witnessed in Italy in the main national media (is COVID a normal flu or the "bubonic plague"?) exceeded the normal dialectics between scientists faced with a relatively new phenomenon.

This point is extremely important because although public debate on disinformation in Italy was very heated, it mainly focused on the circulation of fake news on social media. Yet, it seems that excessive emphasis was placed on this issue considering that only a very small percentage of Italians claimed to have used mainly social media for obtaining information (6.8\% in March and 4.2\% in April, according to Observa). At the same time, it seems that on social media as infections started to rise, reliable information quickly became more dominant (Gallotti et al., 2020).

According to marketing analysists ${ }^{19}$, the huge increase in the volume of traffic registered on social media such as Facebook and Instagram have been much lower than the average increase on the major news sites. We also know that a good part of shared information on social media is provided by traditional news sources (online magazine or newspapers, tv and radio, etc.).

In our opinion, the polyphonic mediatization of the crisis has contributed to declining trust in the institutions themselves, in the information they diffused, and in its early phase, added to the public's confusion. The same investigation by Observa shows that in March 2020 only one third of Italians demonstrated a balanced awareness of the risks (34\%), while another third (29.4\%) tended to minimise, and another third was in a state of fear (36.3\%) (graph 2).

At the same time, also institutional communication contributed significantly to these fragmented interpretations (that vary greatly depending on age, gender, education and geographical position). Research has shown that in general the population tends not to panic, and that people tend to faithfully trust the indicated institutions (Chess, Salomone and Hance, 1995; Tinker et al., 2000). The dependence on emergency messages from the media is, however, high and some errors in communication can influence the exponential growth of widespread anxiety. According to our qualitative textual analysis (carried out from March to May 2020), in Italy, institutional communication was ambiguous, wavering and contradictory.

\footnotetext{
${ }^{18}$ The Italian communications watchdog, AGCOM issued an official warning to audiovisual and radio media service providers in March 2020, advising them to adhere to ethical journalistic practices.

${ }^{19}$ https://www.insidemarketing.it/coronavirus-e-informazione-online-dati/
} 
Ambiguous, because it was not always clearly distinct from political communication. On a central administrative level, the Prime Minister, Giuseppe Conte concentrated much of the governmental communicative production on himself. Very little space was given over to the institutions in themselves or to spokespeople or experts in emergency communication. This contravenes a basic principle of emergency risk communication which avoids excessive exposure of politicians. The media coverage on the Prime Minister was without precedence in the history of the Republic. The level of personalization reached worrying levels on the $8^{\text {th }}$ of March 2020 when Conte made a speech-appeal to the nation announcing lockdown from his personal Facebook profile with the institutional symbols of the prime minister. Only the Protezione Civile ${ }^{20}$ was given comparable communicative space, albeit limited in scope (news bulletins on figures and daily press conference without confrontation with the journalists).

Contradictory due to inefficient coordination of communications between the centre and periphery. The measures adopted in the various phases by the regional or local authorities were often divergent and often without any coordination with central government ${ }^{21}$. Emblematic of this lack of coordination between centre and periphery was the "mystery" of the leaked draft document of the government's decree authorising the closure of the Lombardy region and 14 provinces. A "superficiality" that provoked the uncontrolled exodus of thousands of people from the largest Italian clusters triggering panic across the nation. Although responsibility for the leak has not officially been identified, CNN maintains that it was Lombardy's regional press office that issued the news. Fortunately, the feared mass contagion in Southern Italy never happened but this exodus to some extent legitimised the extension of lockdown to territories that until now have been relatively unaffected by the pandemic.

Wavering because the very early stages of the epidemic were characterised by a certain minimalization. This phase was brusquely followed by information often punctuated with alarmist pressure, the probable reaction to the overall change in strategy to combat the diffusion of the epidemic ${ }^{22}$. In other words, in order to convince the population to live under a regime of quarantine for an indefinite period, the government used a "strong" (alarmistic) communicative register. This choice was probably considered the only one able to beat down the considerable resistance shown by the public, which may also be due to the invisibility of the virus and its various and selective effects. Nevertheless, scientific literature on risk communication warns that this register may have considerable psycho-social side effects (Reynolds, 2014).

This "strong" register of institutional communication was articulated in various ways. Emphasis: communications were shored up by the topos of emergency and the absolute

\footnotetext{
${ }^{20}$ The Italian "Civil protection" is a governmental organ whose functions include risk forecasting, prevention and mitigation as well as disaster management and post-emergency recovery operations. It is an integrated system composed of public and private, central and local structures, working together to guarantee safety and security throughout the country.

${ }^{21}$ Italy witnessed widespread and highly personalised political protagonism from some of the more outspoken local administrators.

${ }^{22}$ On the $3^{\text {rd }}$ February, during a RAI television broadcast, the minister for health, Roberto Speranza and "media" virologist Roberto Burioni, affirmed that the situation was under control, that the virus in Italy was not spreading, that the risk of diffusion of the virus in Italy was practically zero. Less than 10 days later, the website of the ministry published the counter of the number of infections and the number of deceased due to coronavirus.
} 
tones of the apocalyptic literary genre ("nothing will be as it was before"). In addition, the military stance evoked by apodictic political language belongs more to "the hour of irrevocable choices" ${ }^{23}$ than to rational actions that are scientifically based to combat the epidemic. The most recurrent expressions in Conte's speeches were: emergency, nation, union, challenge, to rally, extraordinary, truth, together, courage, sacrifice, responsibility. The abuse of warlike metaphors was ample, regarding both linguistic and iconic register: the images of armoured vehicles used to transport the corpses in Lombardy was a severe blow to the collective imaginary. This was one of the key moments in the handling of the coronavirus emergency, with an enormous emotional impact.

Secondly, from responsibility to "blaming": the whole "\#iorestoacasa" [I'm staying at home] campaign resulted in an inversion of roles between public authorities and citizens, offloading the responsibility of life or death onto the citizens themselves. No serious reflection about social and institutional vulnerability of the country. It seems that only the community can save itself and save others: the whole campaign was constructed with the explicit objective of censuring individual behaviour that was considered "nonaligned", fostering significant forms of social stigmatisation ${ }^{24}$ and moral panic (McLuhan, 1964; Cohen, 1972) ${ }^{25}$, with the consequent identification of scapegoats that created unpleasant social divisions: the social media (Facebook in particular) were used by certain organisations as a "media pillory" to publicly condemn behaviour considered "deviant" (leaving the house, not wearing a face mask, and so on).

An epidemic's tendency to produce scapegoats dates back to antiquity. For thousands of years, epidemics have been perceived as a manifestation of vendettas or divine punishments and the only way to defeat them resides in prayer, fasting, and in designating a scapegoat: foreigners, beggars, lepers, Jews and witches (Cunningham, 2008; Levack, 1995), a phenomenon that reached its climax during the bubonic plague. During the Covid 19 first wave "witch hunting" has affected various social categories; naturally, foreigners (particularly of Asian extract) as societal "Other" in a context (above all in Lombardy) distinguished by years of social representation of the "immigration emergency" (Nicolosi, 2019). Despite the obvious, that the virus was imported from China by entrepreneurs and globalised business people, foreigners were immediately identified as the "enemy", the "Untori" [plague spreaders]. Then, the "runners", those who during lockdown continued to go running outdoors. They were the category most hated and despised. Although physical activity was advocated by WHO during isolation, runners and joggers became subject to a widespread and violent process of social stigmatisation, even hounded, insulted, and ill-treated by local police. Finally, "deserters",

\footnotetext{
${ }^{23}$ The reference is to the speech made by Benito Mussolini on the 10 June 1940 from the balcony of Palazzo Venezia, in which he announced to the crowd a declaration of war on France and Great Britain. For Italy it was the beginning of the Second World War. The decisive passage is introduced by the affirmation: "An hour marked by destiny beats in the skies above our homeland".

${ }^{24}$ During an epidemic, social stigma, which produces isolation, increases the risk of spreading the virus, increase the diffusion of health problems and creates further problems in controlling the epidemic.

${ }^{25}$ A situation in which a collective feeling of fear can be witnessed; a fear which identifies a certain phenomenon as "evil", and harmful to society. These authors have underlined the role of the media in the construction of these conditions. Moral panic always paints a caricatured, popular "devil" on which the community vents its anxieties, according to the renowned "scapegoat" theory (Girard, 1982).
} 
that is, those whose behaviour was considered for necessity or cynicism un-aligned with the highly restrictive laws on personal liberty imposed by the government in those months. Prohibitions which, it must be said, have had varying impact on the population based on discriminatory social variables (social class, gender, ethnic origin, etc.).

Another critical condition of institutional communication was the "numerical" hegemony. In the name of transparency, we have witnessed the colonisation of public discourse by numbers, graphs, and statistics. Transparency, interpreted as information overload was turned on its head. A golden rule of public risk communications suggests avoiding the abuse of numbers and percentages, limiting use to those that are essential to understanding the message, whose meaning must be explained and contextualised (Albanesi et al., 2011). In Italy, "numerisation" was highly controversial. During lockdown, the home page of the Ministry of Health was dominated by graphs illustrating the number of infections and deaths by coronavirus in absolute terms. Every day, at 18.00, the Civil Protection organised a press conference (a "war bulletin") live on television overwhelming the nation with numbers and figures to which millions of Italians attached their personal anguish and hopes. The numbers produced and presented were scientifically contested. We discover now that those data were incomplete, methodologically non-homogeneous by region, and in some cases underestimated (above all in the North), others overestimated (above all in the South). ${ }^{26}$

In addition, the governments' choices were greatly influenced by the statistical forecasts related to the mathematical models produced by Imperial College London. For Italy, the assumptions on which the Imperial College based its model were inexact in many points; the most striking being the non-consideration of the great difference in epidemiological patterns between Lombardy, other regions in the North and the rest of Italy: two (maybe three) different epidemics with completely different incidence and mortality. ${ }^{27}$

The final critical point is the absence of a clear and verifiable exit strategy. In risk communication it is essential to present the citizens/victims with an exit plan and a strategy for recovery (Lundgren and Mcmakin, 2018). In Italy, during the first wave radical lockdown this plan was completely absent. Conflicting and clearly false communications accompanied Italians during a series of deadlines, always disregarded and extended, and considered not credible already in the moment that they were fixed, creating a climate of widespread, deep mistrust.

\footnotetext{
${ }^{26}$ The $4^{\text {th }}$ of May 2020, for example, the Italian Society of Statistics (SIS) in a public statement strongly contested the quality of data collected by Protezione Civile: http://sis-statistica.it/upload/contenuti/2020/files/Statement_della_SIS_su_Covid_DV20200429PC4.pdf

${ }^{27} \mathrm{https} / /$ www.scienzainrete.it/articolo/scarsa-intelligence-dellimperial-e-di-altri-modelli/donato-greco/2020-0511?fbclid=IwAR3SuiX1r-VVMKo_jarm3sFsxwZZ550gP6kkX6fl3KhDRDJgVRuFhFNjMjk
} 


\section{| Conclusions: the "double epidemic" in the play of media mirrors |}

In a very recent article, Demertzis and Eyerman (2020) wondered whether the pandemic of coronavirus will evolve into a cultural trauma in Greece and Sweden. Their answer was clearly negative. At the same time, they recognized that cultural traumas are usually studied in retrospect from a distant point in time, allowing one to isolate a point of origin and then trace the ensuing meaning struggle through a range of forums and media, toward memorialization and the impact with regard to collective memory. This means that it is probably too early to provide apodictic answers.

It is also true that cultural traumas are not the aggregate of individual traumas, nor are they determined by gradations of suffering. Cultural trauma is a specific form of collective trauma, affecting collective identity. According to Neil J. Smelser (2004: 265267), the main ingredients of a cultural trauma are the following:

a) An initial reaction of shock;

b) Many other effective and collective-behaviour reactions: fear, anxiety, terror and some evidence of mental disturbances in a small number of affected people;

c) Widespread collective mourning both spontaneous and officially scheduled;

d) An immediate sense of indelibility of the trauma;

e) A sense of national brooding over the events;

f) A collective endowment of the events with a sacred character (not in any specifically religious sense of the term);

g) The emergence of deliberate efforts to remember the events collectively;

h) Sustained public interest in the remembering process;

i) A culminating sense that national identity had been altered fundamentally.

In our opinion, in Italy we find several clues of all these ingredients. Nevertheless, in this article we do not intend affirm that the coronavirus pandemic surely will evolve into a cultural trauma in Italy. It is still too early for an in-depth analysis of the scientific evidence, the collection of which will require much time. More simply, this article wants to be an exploratory analysis looking for some possible traumatogenic conditions linked to media and institutional communication in Italy.

In fact, as scholars of cultural and communicative processes, we feel directly called into question when people like the renowned epidemiologist John loannis judge that emphatic and excessive information produced serious damage to the collective society (loannidis, 2020). Or when Pier Carlo Sommo, the former General Secretary of the Italian Association of Public Communication, claims: "The only thing for scholars of crisis communication to do is to collect copious amounts of material and use it at University to teach our future communicators how not to do crisis communication". 
The most striking aspect we would like to emphasize is the government's decision to strategically model institutional communication in an "alarmistic" register. Instead, we would have expected a different approach that took into account the considerable evidence produced in recent years by social researchers on public risk communication (Cerase, 2017). It is important to point out that a wrong institutional crisis communication can put social order at risk.

The objective conditions of a disastrous event such as the pandemic we are experiencing are a necessary condition for a collective trauma to occur. However, it is by no means a sufficient cause. Equally, history teaches us that social, political, and cultural consequences of epidemics are not necessarily correlated to the number of victims (Snowden, 2019). This is because symbolic traumas that strike the collective imagination can also be more radical than the real, material, corporeal ones. ${ }^{28}$

For this reason, it is particularly important to analyse media narratives and representations. Similarly, it is very interesting to study the cultural reaction in geographical areas with dissimilar "material" impacts of the catastrophic event: that is, distinct areas with dissimilar negative harmful consequences (intensity, number of infected, number of deaths, etc.). This geographical differentiation could allow us to make hypothesis on the impact of representative and symbolic components in defining the traits of collective trauma. Some preliminary and general considerations can be made, and some important traces can be found.

The phenomenological data gathered throughout the national territory after the first wave describe widespread traumatic neurosis, with no relevant differences between North and South: citizens recount that they are in a state of shock, numb, disoriented. Several studies reveal increase both in the North and in the South, in suicide rates during the covid 19 pandemic and the "Istituto Superiore di Sanità (ISS)" admits that communication has been an important risk factor explaining this increase, as «it may have exacerbated fear and anxiety $\gg .{ }^{29}$ Probably, there is nothing more terrifying than a formless danger, that is non-representable, nor containable in time or space and media and institutional communication can have exalted, rather than reduced, these characters.

The findings from "Observa" for the month of April at the height of the "\#iorestoacasa" campaign, reveals a sociological picture that is congruent with this reading. Compared to the month of March, the percentage of those who affirmed that staying at home with food supplies and drugs was the only measure that would be effective in avoiding contagion (we categorized this position as "fear") increased by $30,6 \%$ (from $36,4 \%$ to $67 \%$ ). The number of those who believed that the epidemic was out of control (14\%) and that avoiding contagion was impossible $(6 \%)$ remained stable (also these positions

\footnotetext{
${ }^{28}$ According to Snowden (2019), despite the enormous number of people affected by the so-called "Spanish Flu", it impacted less on society as a whole (see also Crosby, 2003) compared to the "black plague", which although limited in numbers, had a strong impact on all areas of social life, from art, religion and economic processes, to the promotion of the modern state (the communities had to get organised in order to prevent the spread of the disease, and therefore they needed a central authority).

29 ISS is the main technical and scientific organism supporting the Italian Health National Service. See: https://www.epicentro.iss.it/mentale/giornata-suicidi-2020-fenomeno-suicidario-italia
}

SHJ, I (I) (202I) pp. 103-I26. ISSN: 2792-3967 
have been categorized as "fear"). According to graph 3, the percentage of those who minimalised the risk reduced drastically (from $29,4 \%$ to $3.7 \%$ ).

The campaign of institutional communication has focused on the government's strategic objective: the creation of a cultural and psychological framework that would encourage a radical lockdown. Somehow, during the first wave, institutional communication and lockdown became two sides of the same coin.

We can say that the goal has been achieved, but the consequences of this strategy could have been serious. Under a psycho-social point of view the impact has yet to be evaluated. Nevertheless, after the lockdown, seven hundred Italian psychologists, psychotherapists and psychiatrists signed an appeal ${ }^{30}$ to the institutions to highlight the «psychological damage that lockdown and the dangers of a contradictory communication based on fear». The main traumas registered today by psychologists are the following:

- Isolation, with repercussions on somatic levels and reduced resilience;

- Symptoms of depression (loss of motivation, self-esteem, physical and cognitive fatigue;

- Violence and aggression (an increase in domestic violence and conflicts between individuals was registered);

- Paranoid suspicion (search for the plague spreader);

- Sense of incoherence;

- Individual and social control;

- Technological overdose;

- Compromised development and growth in minors;

The picture that emerges shows overlapping individual and collective dimensions. The Centre for Social Investment Studies (Censis) defined Italy as the "peninsula of fear" in a report published in July 2020. ${ }^{31}$ According to the report, $68 \%$ of Italians claim to be afraid. This fear is rooted in the entire Italian territory and cuts across various social groups. The percentage increases to $72 \%$ among millennials and women, touches $75 \%$ in the South, exceeds $76 \%$ the self-employed (business people, entrepreneurs) and reaches $82.6 \%$ amongst those with the lowest incomes. In December 2020, a new Censis report has revealed that fear is the prevailing sentiment for $73,4 \%$ of Italians. Censis again notes that $57.8 \%$ of Italians are willing to give up personal freedoms to protect collective health; $77.1 \%$ ask for severe penalties for those who do not wear a mask; $56.6 \%$ ask for jail for those infected who violate the quarantine; $31.2 \%$ want to deny treatment to those who have become ill due to irresponsible behaviour (graph 4).

Fear becomes the main emotional regulator in this new era. In research conducted by the Gaslini Institute in Genoa to monitor the impact of the Covid19/Sars2 pandemic on the psychological state of children and families, it emerges that $65 \%$ of children under

www.comunicatopsi.org

https://www.censis.it/economia/italiani-impauriti-boom-del-risparmio-l\%E2\%80\%99aumento-di-liquidit\%C3\%A0-nel-lockdownvale-quanto-il 
the age of six, and $71 \%$ of under $18 \mathrm{~s}$ had suffered from behavioural issues and symptoms of regression. The level of the children's dysfunctional behaviour correlates significantly with the level of parental circumstantial malaise.

Our thesis is that this widespread condition brings together the real and imaginary, the material epidemics and the immaterial one. They both characterised the whole country, but the former was particularly concentrated in the North. This is because, as already said, Italy has lived two different epidemics. One which is dramatically ferocious that has mostly affected certain areas in the North of the country: it is there that by far the biggest number of deaths and physical suffering have been concentrated, as well as the critical organisational, logistic and health service issues. It is on these issues that the majority of traumas are registered that can be ascribed to experiences that are as real as they are dramatic: a mother admitted to intensive care, a father who died in isolation, far from loved ones; deaths that have not been able to find the cathartic release of a funeral; exhausted medics overwhelmed by feelings of impotence, hospital wards hit by tidal waves, which in turn have become clusters where infection breeds for the patients and the caregivers; the ill and the dead totally abandoned and alone in nursing homes; improvised healthcare that has only accelerated patient fatalities. All this has produced individual, yet widespread and therefore collective trauma based on real, material, corporeal experience. An unreal silence, broken only by the incessant sound of ambulance sirens which race from one end of the city to the other.

Simultaneously, due to the perverse effects of distorted mirrors (the combination of media and institutional communication), the rest of the country has lived a second pandemics; more imagined than material. In this case, the collective trauma was predominantly based on a symbolic elaboration. Here, anxiety, fear, panic, and neurosis were linked to a dystopic mirage, built on the expectation of an event that never took place with the dreaded virulence. ${ }^{32}$ In many regions of Southern Italy, during the "first wave", perhaps the most striking of contradictions in this "double epidemic" is represented manifestly by makeshift hospital wards set up for the COVID emergency that then remained grotesquely empty.

In a certain way, a part of the country collectively practiced "captromancy", the divination of visions perceived via a mirror presumed to be magic (the media). A practice whose symbolic, deep, roots are linked to some archetypal figures. However, this practice has ambivalent symbolic roots: the oracles, in fact, could bring the hidden "truth" to surface, but also risk having their "eyes pecked out by crows".

This "double" epidemic both real and imagined promise to leave their mark. To the collective trauma, Italians have responded with a new symbolic ritual: singing from balconies, the rounds of applause, the rainbows, the candles on show, the processions

\footnotetext{
${ }^{32}$ According to ISTAT, from the $20^{\text {th }}$ of February to the 31 th of March, the South of Italy registered $+1,9 \%$ of deaths $(+7,7 \%$ at the end of 2020), if compared with the average 2015-2019. Some densely populated regions like Sicily registered $-2 \%(+5,8 \%$ at the end of 2020); Campania $-1 \%$ ( $+7 \%$ at the end of 2020). On the contrary Lombardy registered $+144 \%(+36,6 \%$ at the end of 2020$)$. For this reason, in May 2020 ISTAT and ISS defined the impact of COVID 19 on mortality on the South of Italy very low ("molto contenuto"): https://www.istat.it/it/files/2020/05/Rapporto_Istat_ISS.pdf
} 
of sacred symbols, collective prayer, the creation of new national heroes (doctors and health care workers). In this, social media have played a fundamental role. Since the start of the emergency, flash-mobbing and initiatives that evoked national unity have multiplied. Hashtags like \#uniticelafaremo, [we'll get there] \#andràtuttobene [Everything will be alright] became very popular. Moreover, after the legal institution of the celebration of the national day in memory of the victims of the coronavirus epidemic, the first celebration took place on 18 March 2021 with official initiatives from Bergamo to Palermo.

The condition of siege (an external and invisible enemy) and the initial feeling of international isolation have produced a nationalistic tremor, which in reality was rather the expression of a deep desire for community and linked to the realisation that only by being united and with the collaboration of everyone would it be possible to get through such a terrible crisis. In social media, certainly "home" was the most common symbolic topos. Refuge, but also prison. Communication in this sense was contradictory and ambivalent. In this sense, besides fear, ${ }^{33}$ on social media we witnessed much irony. In fact, people, above the young, understood how to activate processes of sarcastic selfproduction in order to release tension and exorcise angst. Furthermore, social networks were less a source of information than amplifiers of common emotions: a space for social debate where one could share advice on how to survive quarantine, or for reflecting on its effects or possible solutions.

In this respect, one of the aspects that appears to be promising for further future research developments concerns the theme of rites. Secular or religious, embodied or mediated, the rites associated with the pandemic have become increasingly a part of everyday life. This is because, as anthropologists explain, disastrous events destroy the two main points of reference: the territory, (in this case abandoned), and the community (disconnected by the sudden deaths, the deserted streets, and "social distancing"). In these exceptional times, old rites are adapted, and new ones emerge to respond to these disconcerting changes in routine. Through the rites of emergency, the drama is put in communion, the emotions generated by it are expressed, and one attempts to absorb the shock, the sudden uncertainty is coped with by emotion. In sum, the trauma is managed collectively.

Nevertheless, the rite can have a dangerous, consolatory function (Gugg, 2014), because it can give a community the illusion of being immune to a successive disaster and generate a false sense of security. Or, rites can serve to remove the community's sense of guilt by attributing the causes of the disaster to scapegoats. Or to re-establish the pre-existent social order (resilience) without reflexively reasoning on the political and social responsibilities and on the possible and necessary changes.

\footnotetext{
33 The observatory, AGI COVID 19 ["Agenzia Giornalistica Italiana", Italian Agency of Journalism] has shown that the sentiment of the conversations on social media is negative: disappointment and anger are the feelings that prevail (respectively $38 \%$ and $22 \%$ of online conversations), but also and inevitably, fear (10.7\%).
} 


\section{References |}

Albanesi et al. (2011). La comunicazione istituzionale dei rischi. Linee guida. Bologna: Università di Bologna.

Alexander, J.C. et al. (2004). Cultural Trauma and Collective Identity. Berkeley: California university Press.

Anderson, B. (1991). Imagined Communities. London: Verso.

Anzera, G. (2014). La comunicazione di emergenza nel contesto contemporaneo. In F. Comunello (Ed.). Social media e comunicazione d'emergenza. Milano: Guerini, p. 13-32.

Ball-Rokeach, S. J. and DeFleur, M. L. (1976). A dependency model of mass-media effects. Communication Research, 3, 3-21.

Barthes, R. (1980). La chambre claire. Note sur la photographie. Paris: Gallimard.

Beck, U. (2000). La società del rischio. Verso una seconda modernità. Roma: Carocci.

Bishop, S. et al. (2015). See the world through non rose-coloured glasses: anxiety and the amygdala response to blended expressions. Frontiers in Human Neuro-Science, 9 (152).

Brown, P. (2020). Studying COVID-19 in light of critical approaches to risk and uncertainty: research pathways, conceptual tools, and some magic from Mary Douglas. Health, Risk and Society, 2(1), 1-14.

Burke, P. (2017). Testimoni oculari. Il significato storico delle immagini. Roma: Carocci.

CDC (2014). Crisis emergency risk communication. Atlanta: Center for Desease Control and Prevention.

Censis (2020). 54 Rapporto sulla situazione sociale del Paese/2020, Roma.

Cerase, A. (2017). Rischio e comunicazione. Teorie, modelli, problemi. Milano: Egea.

Charcot, J. M. and Richer, P. (1887). Les démoniaques dans l'art. Paris : Delahaye et Lecrosnier Editeurs.

Chess, C., Salomone, K.L., Hance, B.J. (1995). Improving risk communication in government: Research priorities. Risk Analysis, 5, 127-135.

Cohen S. (1972). Folk, devils and moral panics. St. Albans: Paladin.

Crosby, A. W. (2003). America's Forgotten Pandemic. Cambridge: Cambridge University Press. 
Cunningham, A. (2008). Epidemics, pandemics and the doomsday scenario. Historically Speaking, 9(7), 29-31.

Debord, G. (1967). La société du spectacle. Paris: Éditions Buchet-Chastel.

Del Porte, C. and Veyrat-Masson, I. (eds.) (2018). La puissance des images. Paris: Nouveau Monde Éditions.

Demertzis, N. and Eyerman, R. (2020). Covid 19 as cultural trauma. American Journal of Cultural Sociology, 8, 428-450.

Durkheim, E. (1912). Les formes élémentaires de la vie religieuse. Paris: PUF.

Erikson, K. (1991). Notes on Trauma and Community. American Imago, 48 (4), 455-472.

Erll, A. and Nünning, A. (eds) (2010). A companion to cultural memory studies. Berlin: De Gruyter.

Erll, A. and Rigney, A. (eds) (2012). Mediation, remediation and the dynamics of cultural memory, Berlin: De Gruyter.

Fehrenbach, H. and Rodogno, D. (2016). Humanitarian photography. A history. Cambridge: Cambridge University Press.

Fischoff, B., et al. (2018). Public understanding of Ebola risks: Mastering an unfamiliar threat. Risk Analysis 38, 71-83.

Freud, S. (1913). Totem and taboo, some points of agreement between the mental lives of savages and neurotics. Boston: Beacon Press.

Fritz, C. (1968). Disasters. In International Encyclopedia of the Social Sciences (Volume III). New York: Macmillan.

Gallotti, R. et al. (2020). Assessing the risks of 'infodemics' in response to COVID-19 epidemics. Nat Hum Behav 4, 1285-1293 doi.org/10.1038/s41562-020-00994-6

Garfin, D. R., Thompson, R., \& Holman, E. A. (2018). Mental and physical health effects of acute stress following traumatic events: A systematic review. Journal of Psychosomatic Research, 112: 107-113.

Gesser-Edelsburg, A. and Shir-Raz, Y. (2017). Risk communication and infectious diseases in an age of digital media. London-NY: Routledge.

Giddens, A. (1990). The consequences of modernity. Cambridge: Polity Press. 
Gilbert, C. (1998). Studying Disaster. Changes in the main conceptual tools. In E. L. Quarantelli (Ed.), What is a disaster. London: Routledge.

Girard R. (1982). Le bouc émissaire. Paris: Grasset.

Gugg, G. (2018). Devozione tellurica : antropologia dei riti religiosi in tempo di crisi. M@gm@, 16(3)

Holman, E. A. et al. (2020). Media exposure to collective trauma, mental health, and functioning: Does it matter what you see? Clinical Psychological Science, 8, 111-124.

loannidis, J. (2020). Coronavirus disease 2019: The harms of exaggerated information and non-evidence-based measures. European Journal of Clinical Investigation, 50:e, 13222: $1-5$.

Janet, P. (2016). Trauma, coscienza, personalità. Milano: Raffaello Cortina.

Jones, N. M. et al. (2017). Distress and rumor exposure on social media during a campus lockdown. PNAS, 114 (44) 11663-11668.

Lagadec, P. (1988). Ėtats d'urgence. Paris: Seuil.

Langford, I. H., Marris, C., O'Riordan, T. (2001). Public reactions to risk: Social structures, images of science and the role of trust. In P. Bennet and K. Calman (Eds.). Risk communication and public health. Oxford: Oxford University Press, 33-50.

Levack, B. P. (1995). The witch-hunt in early modern Europe. New York: Routledge.

Luhmann, N. (1993). Risk. A sociological theory. New York: Aldine de Gruyter.

Lundgren R. and Mcmakin, A. (2018), Risk communication. Hoboken (NJ): Wiley.

Mantovani, C. and Ravarotto, L. (2016). Rischi alimentari e infografiche. In L. Ravarotto (Ed.). Comunicare il rischio alimentare. Roma: Carocci, 64-71.

Mcluhan, M. (1964). Understanding media. New York: McGraw-Hill.

Meek, A. (2010). Trauma and media. Theories, histories and images. New York: Routledge.

Nicolosi, G. (2019). La migrazione come risorsa simbolica dello storytelling politico. Immaginario emergenziale, discorsi d'odio e media in Italia. Im@go. A Journal of the Social Imaginary, 14 (VIII), 101-123.

Observa (2021). Annuario scienza tecnologia e società: Tra pandemia e tecnologie digitali. Bologna: il Mulino. 
Parikka, J. (2019). Archeologia dei media. Nuove prospettive per la storia e la teoria della comunicazione. Carocci : Roma.

Pidgeon, N., Kasperson, R. E. and Slovic, P. (Eds.) (2003). The social amplification of risk. Cambridge: Cambridge University Press.

Pinotti, A. and Somaini, A. (2016). Cultura visuale. Immagini, sguardi, media, dispositivi. Torino: Einaudi.

Quammen, D. (2013). Spillover. Animal infections and the next human pandemic. New York: WW Norton \& Co.

Quarantelli, E. L. (Ed.) (1998). What is a disaster. London: Routledge.

Reynolds, B. (Ed.) (2014). Crisis emergency risk communication. Atlanta: Center for Desease Control and Prevention.

Riva, G. (2018). Fake news. Bologna: il Mulino.

Slovic, P. (2000). The perception of risk. London: Earthscan Publications.

Smelser, N. J. (2004). September 11, 2001 as cultural trauma. In J. C. Alexander et al. (2004). Cultural trauma and collective identity. Berkeley: California university Press, 264282.

Snowden, F. M. (2019). Epidemics and society. From the black death to the present. New Haven: Yale University Press.

Sturloni, G. (2018). La comunicazione del rischio per la salute e per l'ambiente. Milano: Mondadori.

Tinker, T.L. et al. (2000). Assessing risk communication effectiveness: Perspectives of agency practitioners. Journal of Hazardous Materials, 73, 117-27.

World Health Organization (2003). Severe acute respiratory syndrome (SARS): Status of the outbreak and lessons for the immediate future. Geneva: World Health Organization.

Wolf, M. (1985). Teorie della comunicazione di massa. Milano: Bompiani.

Wright, C. (1959). Mass communication: A sociological perspective. New York: Random House.

\section{| Appendix |}


Communication, fear, and collective trauma in first wave Covid-19

"double epidemic" in Italy: Traces and clues

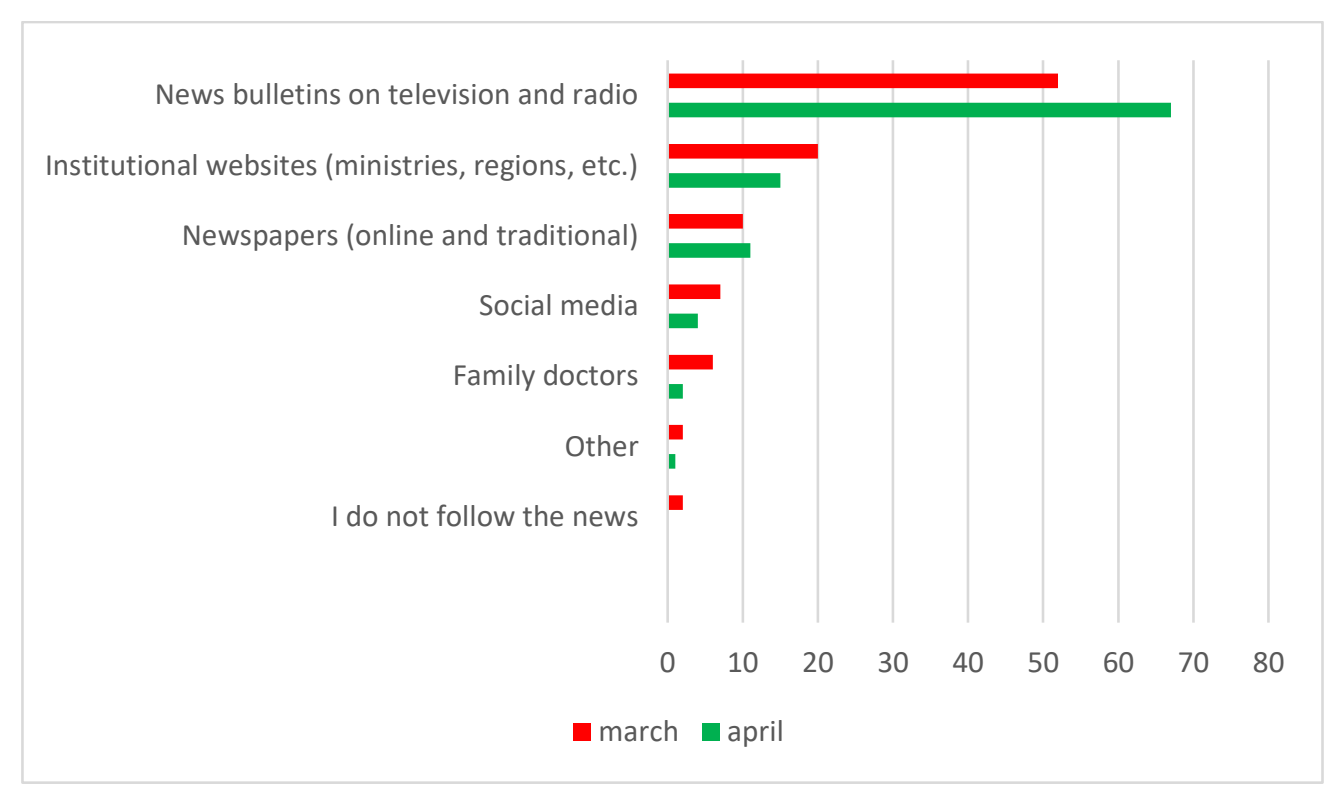

Graph I. Italians and information during lockdown (Source: Observa, 202I: https://www.observa.it/).

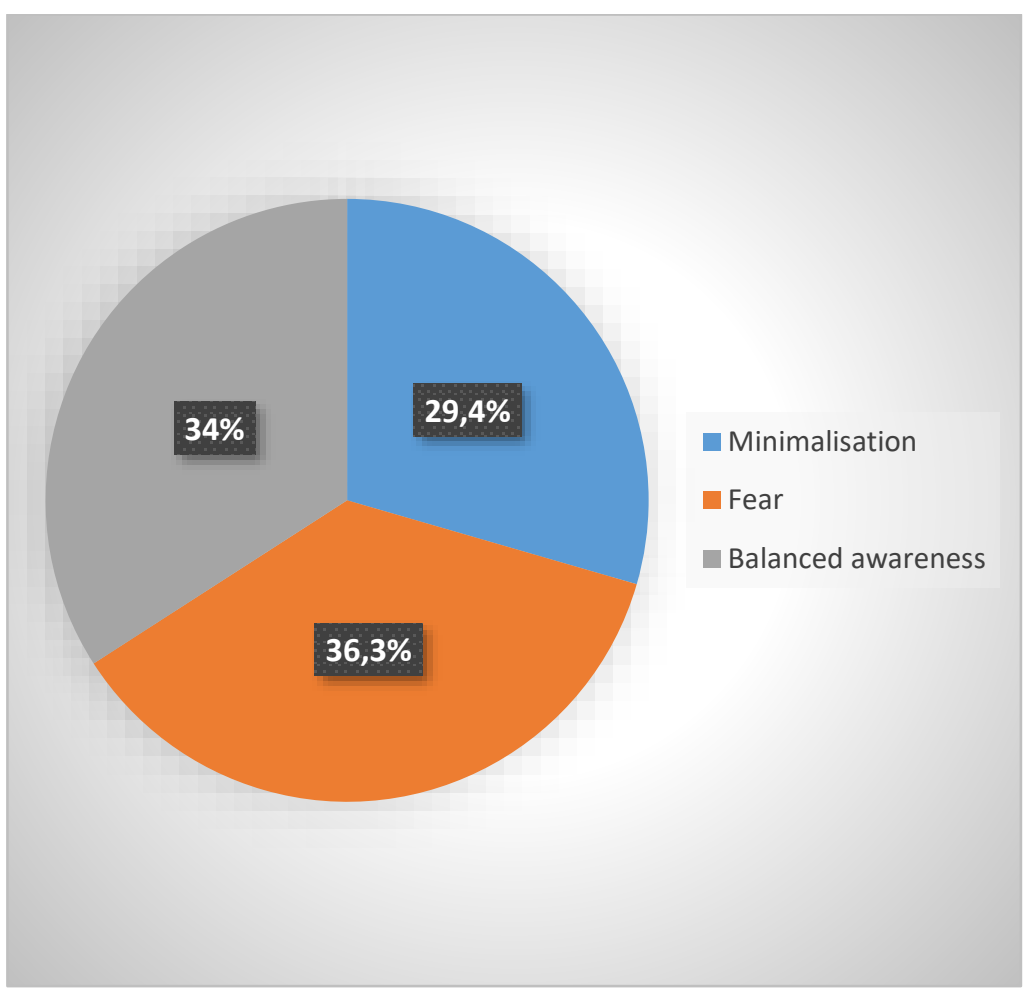

Graph. 2 The Italians' perception of the risk coronavirus (March 2020). Data elaborated by Observa, 2021. 


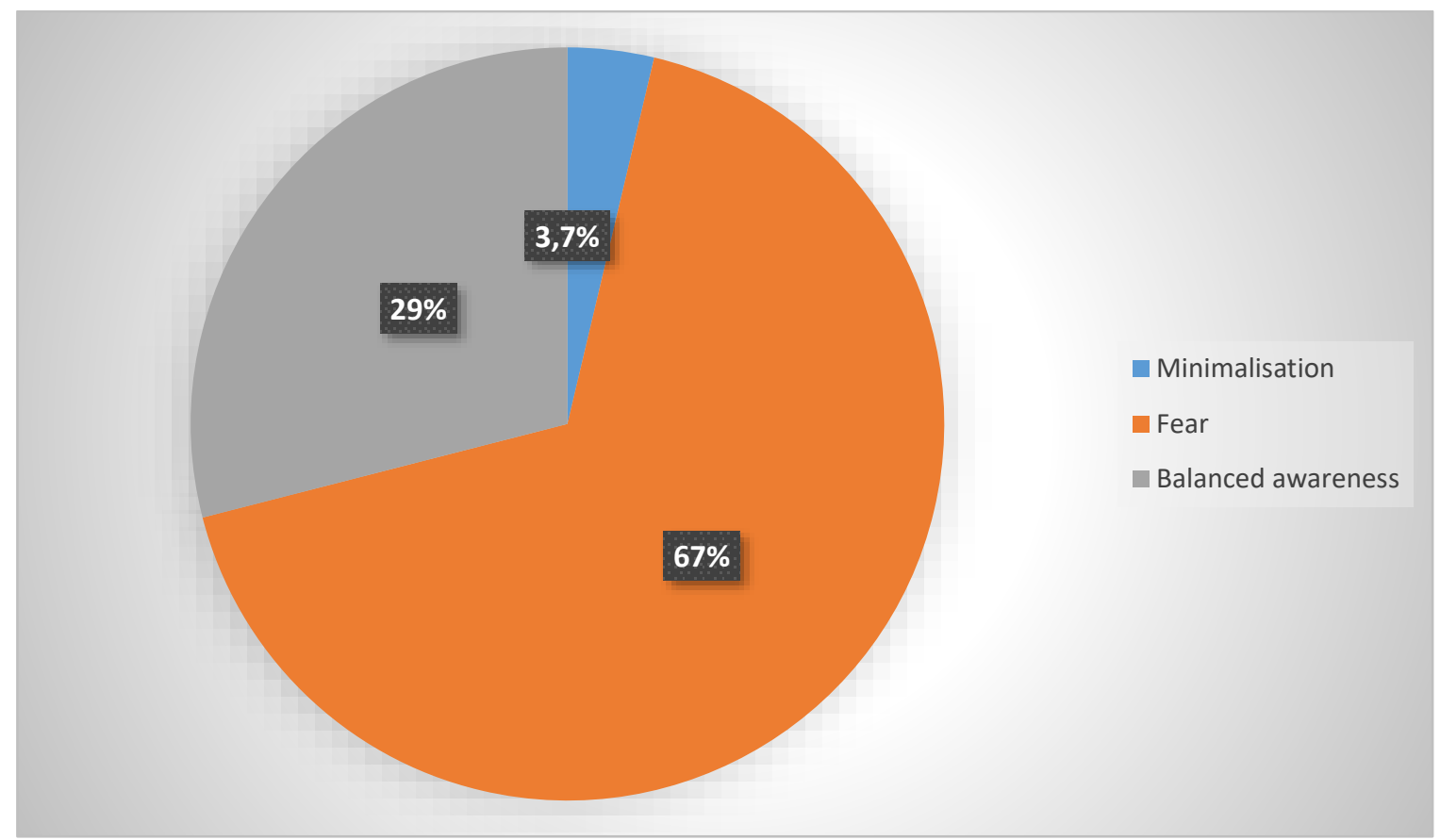

Graph. 3 The Italians' perception of the risk coronavirus (April 2020). Data elaborated by Observa, 202 I.

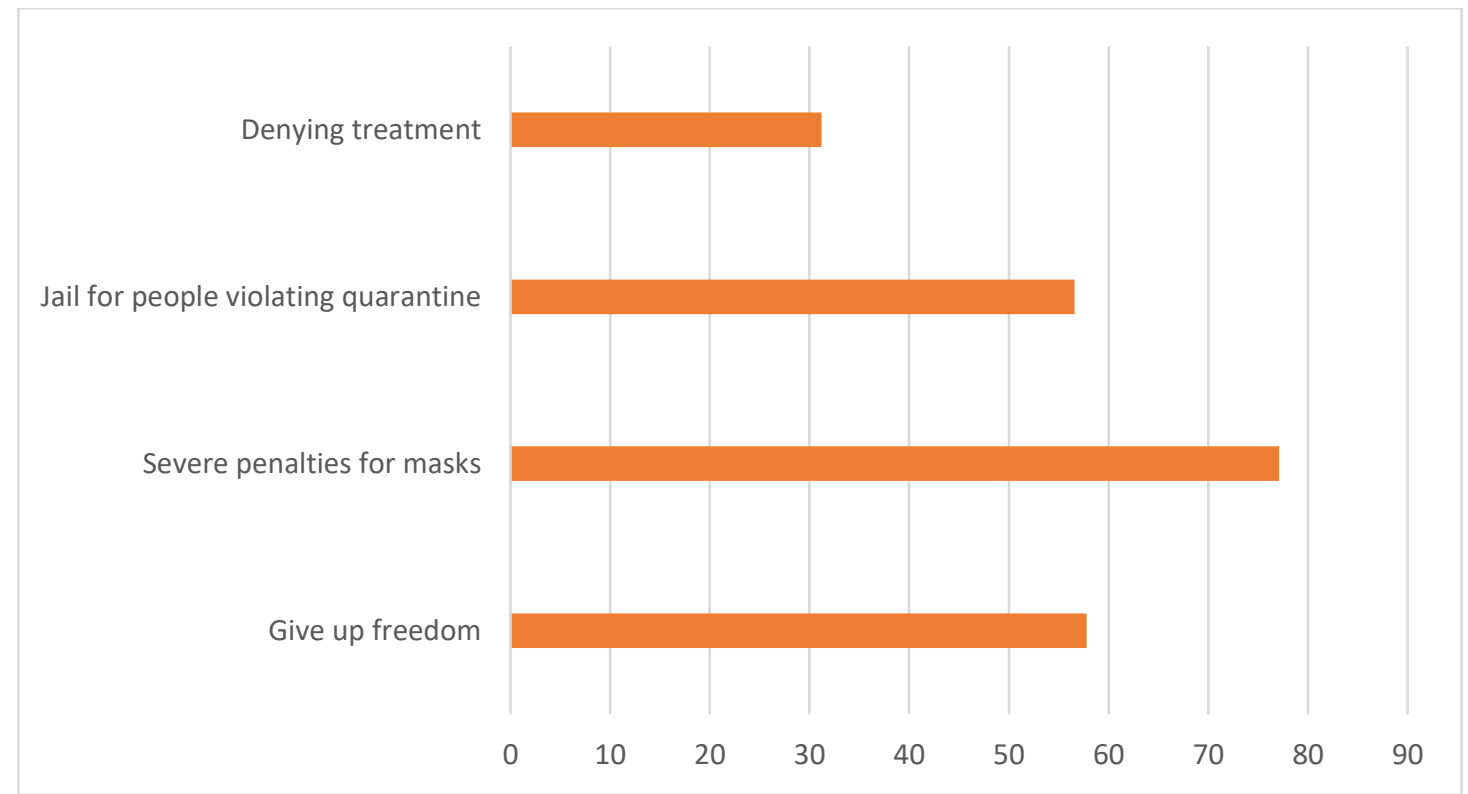

Graph. 4 Data from “54 Rapporto sulla situazione sociale del Paese” (Censis, 2020).

\section{Funding |}

This contribution has been supported by the University of Catania research programme 2020-2022 funding line number 2 . 


\section{| Biographical note |}

Guido Nicolosi is Associate Professor in Sociology of culture and communication at the Department of Political and Social Sciences, University of Catania (I), where he is Chair of the MA Program in Sociology of networks, information and innovation. He teaches sociology of culture and media studies. He got his $\mathrm{PhD}$ at the Wageningen University $(\mathrm{NL})$ and is member of several research teams in national and international research programs. He has been visiting scholar at the Universities of Exeter (UK), Aberdeen (UK) and Paris (F). He has been resident fellow at the Institute for Advanced Study (IEA) of Nantes (F) in 2014. He has been visiting professor at the University of Paris I Panthéon-Sorbonne in 2019. Currently he is Deputy Rector for Communication at the University of Catania and member of the technical committee supporting the special office for «health communication » of the Regional Government of Sicily. 